\title{
Rudolf Weber (1922-2015): a driving force in the transition of developmental biology into a molecular and cellular science
}

\author{
Daniel Schümperli ${ }^{1}$
}

Received: 14 February 2016 / Accepted: 14 February 2016/Published online: 27 February 2016

(C) Springer-Verlag Berlin Heidelberg 2016

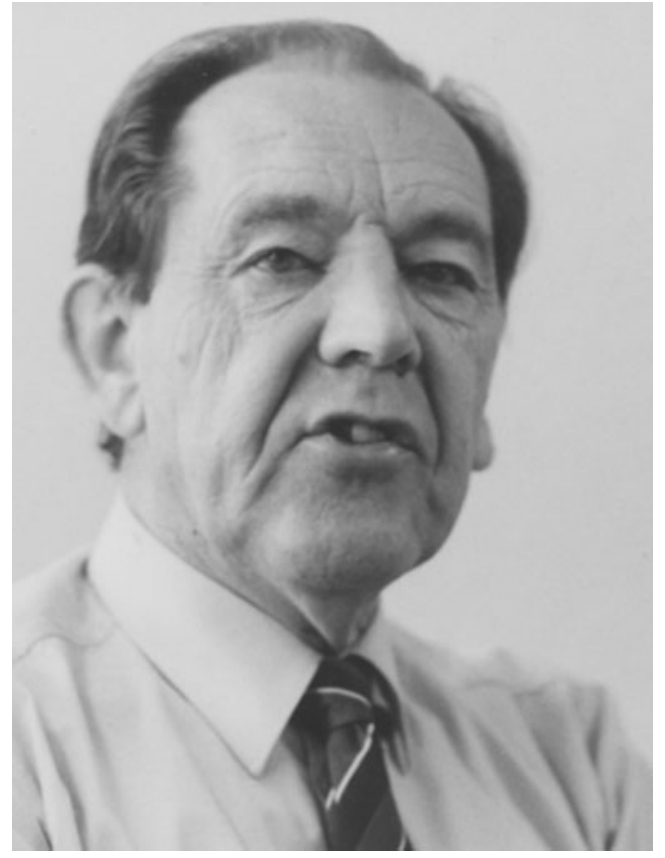

Prof. Dr. Rudolf Heinrich Weber passed away on December 23, 2015, at the high age of 93 years. Succeeding Fritz Baltzer and Fritz Erich Lehmann, he became the third in a line of outstanding developmental biologists at the University of Bern, Switzerland. Throughout his career, he helped shape modern developmental biology by introducing and promoting biochemical and molecular techniques.

Daniel Schümperli

daniel.schuemperli@izb.unibe.ch

Institute of Cell Biology, University of Bern, Baltzerstrasse 4, 3012 Bern, Switzerland
Rudolf Weber was born in Basel, Switzerland, on September 27, 1922. He studied biology in Basel and obtained his $\mathrm{PhD}$ in 1949 under the supervision of Adolf Portmann. His thesis (Weber 1949) had a developmental topic (Transitory closures of distant sensory organs during the embryonic period in amniotes; translated from German), yet its character was descriptive and comparative, quite in line with Portmann's tradition of comparative morphology and evolutionary biology. Weber later admitted that he was never quite happy with his thesis, as his main interest had always been to understand the mechanisms that drive development. He was convinced that this could not be achieved solely by morphological descriptions and comparisons, but that experiments and in particular chemical and biochemical methods had to be used as well.

After his graduation, Weber worked and acquired experiences in different fields, countries, and institutions, in particular at the University of Uppsala (Sweden), the Division de Malarialogia in Maracay (Venezuela), the Swiss Tropical Institute in Basel, and the Carlsberg Laboratories in Copenhagen (Denmark). A turning point in his career was 1954, when he accepted an assistant position offered by Fritz Erich Lehmann at the Zoological Institute of the University of Bern. This institution was to remain his academic home until his retirement in 1988.

In 1954, Lehmann had just succeeded Fritz Baltzer as institute director, and both of them were world-renowned specialists of developmental physiology (Entwicklungsphysiologie), the term used for the research field of developmental biology at the time. A native of Bern, Baltzer had studied with Theodor Boveri in Würzburg (Germany) and with Hans Spemann in Freiburg im Breisgau (Germany). These experiences had influenced him, once he was appointed professor in Bern, to study the roles of chromosomal and cytoplasmic determinants in various systems, including sea urchins (Baltzer 1910), the worm Bonellia (Baltzer 1928), and amphibians (newts) (Baltzer 1922; Baltzer 1952). His work was driven by the urge to integrate information from 
cytology, genetics, experimental morphology, and evolutionary systematics in order to reach a deeper understanding of developmental processes and principles. Similarly, Lehmann, after basic studies in Zürich, had been trained by some of the great pioneers, such as Hans Spemann and Ross G. Harrison in New Haven (USA). Lehmann had joined Fritz Baltzer at the University of Bern in 1929. One of his main interests was to study the influence of chemical substances on developmental processes. This approach allowed him, among other things, to reveal regional specificities within the newt organizer (Lehmann 1938). He also studied the effects of chemicals on cell proliferation and hoped that these studies could contribute to the understanding and perhaps curing of abnormal cell growth in tumors. For this purpose, he had established, in 1950, the first colony of African clawed frogs (Xenopus laevis) at a Swiss university. He had obtained a few founder animals from CIBA in Basel who kept them for bioassays of pregnancy hormones. Lehmann mainly used the tadpoles to study the regeneration of tail tips (Lehmann and Scholl 1962). Another of Lehmann's interests was the subcellular organization of cells. Therefore, he had urged the university authorities to establish an electron microscopy lab in Bern in the early 1950s.

Thus, when Rudolf Weber joined the Zoological Institute of the University of Bern in 1954, he found a well-equipped research institution with a long and successful tradition in developmental biology. Some of the main ingredients that suited Weber's intentions were (i) the tradition, initiated by Baltzer and continued by Lehmann, of integrating various disciplines into developmental studies; (ii) the interest that Lehmann and himself shared in chemical/biochemical and cell biology techniques and the availability of (iii) an electron microscope; and (iv) a well-established Xenopus colony. A fifth ingredient that turned out to be important for Weber's later career had to do with the relatively small size of the university: The fraction of good students was not different from bigger, more famous institutions, but there were a smaller number of researchers who could try to attract the best ones.

In both aspects, his own research as well as the recruitment and training of excellent students, Rudolf Weber was extremely successful. This is documented by countless publications and by the fact that he rapidly climbed up the academic ladder and became full professor in 1968.

Even though Rudolf Weber initially did work on Lehmann's tail regeneration project, he soon attacked a different problem which he found more interesting. For his own line of research, he chose to study the mechanisms of metamorphosis that convert the tadpole to an adult frog. His most exciting discovery, which made it into the textbooks, was that metamorphosis is a result of autonomous reactions of the different cells to the hormone thyroxin. Thus, he could show in 1962 that isolated tail tips from tadpoles that were maintained in a culture medium regressed in a similar way as in the whole animal when thyroxin was added (Weber 1962; Weber 1966).
In the early 1970s, Rudolf Weber was one of the first developmental biologists who started to study gene regulation, realizing that this could be one of the major mechanisms driving development. He was helped in this endeavor by his outstanding electron microscopist Toni Wyler and by a series of extremely talented $\mathrm{PhD}$ students, all of whom later held independent group leader positions in various countries and institutions: Gerhart Ryffel (graduated 1973), Peter Wellauer (1973), Ueli Schibler (1975), Otto Hagenbüchle (1976), Walter Wahli (1977), and Barbara K. Felber (1981). ${ }^{1}$ After initial studies on the transcriptional reactions of various Xenopus tissues during metamorphosis (Hagenbüchle et al. 1976; Ryffel and Weber 1971; Ryffel and Weber 1973; Stadler and Weber 1970), they decided to study the induction of vitellogenin synthesis by estrogen in adult male Xenopus liver (Wahli et al. 1976). The vitellogenin genes turned out to be the most complex genes analyzed at the time. Moreover, with Xenopus being a pseudotetraploid organism, there were a lot of genes to characterize. Weber's group managed to do this in a very short time and in an impressive series of publications (Felber et al. 1980; Gerber-Huber et al. 1981; Huber et al. 1979; Jaggi et al. 1980; Ryffel et al. 1981; Ryffel et al. 1977; Ryffel et al. 1980; Wahli et al. 1981; Wahli et al. 1979; Wahli et al. 1980; Wahli et al. 1978). In these years, the Weber group also published important work on mitochondrial DNA, ribosomal RNA, and the albumin and globin genes of Xenopus.

These were truly exciting years. Weber and his team helped to establish Xenopus as one of the most important model organisms for developmental research. Moreover, they were one of the important drivers introducing molecular biology techniques and eventually the analysis of cloned genes into developmental biology and into biomedical research in the broader sense.

Rudolf Weber was also a dedicated but demanding teacher. Even though students often made fun of his difficult-tounderstand articulation, they particularly liked his practicals, which were spiked with high-class specimens, electron microscopic images, and experiments directly taken from Weber's scientific work.

Last but not least, Rudolf Weber was also very active in promoting science. He served as institute director for many years and as dean of the Science Faculty of the University of Bern in 1973/1974. He incessantly promoted biological research in Switzerland, e.g., as the vice president of the Swiss Natural Research Society (today the Swiss Academy of Sciences) and as a member of the Research Council of the Swiss National Science Foundation. He also organized numerous scientific meetings and was on the editorial board of various scientific journals. From 1975 to 1988, he was editor in chief of the journal Wilhelm Roux's Archives for Developmental Biology, which was renamed Development Genes and Evolution in 1996.

\footnotetext{
${ }^{1}$ I apologize to all of Rudolf Weber's excellent postdocs and students whom I did not name here for reasons of space.
} 


\section{References}

Baltzer F (1910) Über die Beziehung zwischen Chromatin und der Entwicklung und der Vererbungsrichtung bei Echinodermenbastarden. Arch Zellforsch 5:497-621

Baltzer F (1922) Über die Herstellung und Aufzucht eines haploiden Triton taeniatus. Verh Schweiz Naturf Ges Bern:248-249

Baltzer F (1928) Über metagene Geschlechtsbestimmung und ihre Beziehung zu einigen Problemen der Entwicklungsmechanik und Vererbung (aufgrund von Versuchen an Bonellia). Verh Deutsch Zool Ges 32:273-325

Baltzer F (1952) Experimentelle Beiträge zur Frage der Homologie. Xenoplastische Transplantationen bei Amphibien Experientia 8: 285-324

Felber BK et al (1980) Isolation and translation in vitro of four related vitellogenin mRNAs of estrogen-stimulated Xenopus laevis. Eur J Biochem 105:17-24. doi:10.1111/j.1432-1033.1980.tb04469.x

Gerber-Huber S, Felber BK, Weber R, Ryffel GU (1981) Estrogen induces tissue specific changes in the chromatin conformation of the vitellogenin genes in Xenopus. Nucleic Acids Res 9:2475-2494

Hagenbüchle O, Schibler U, Weber R (1976) Incorporation of [5$3^{\mathrm{H}}$ ]uridine into ribonucleotide pools and RNA during thyroxineinduced metamorphosis of Xenopus laevis tadpoles. Mol Cell Endocrinol 4:61-77. doi:10.1016/0303-7207(76)90027-7

Huber S, Ryffel GU, Weber R (1979) Thyroid hormone induces competence for oestrogen-dependent vitellogenin synthesis in developing Xenopus laevis liver. Nature 278:65-67

Jaggi RB, Felber BK, Maurhofer S, Weber R, Ryffel GU, Muellener D (1980) Four different vitellogenin proteins of Xenopus identified by translation in vitro. Eur J Biochem 109:343-347. doi:10.1111/j. 1432-1033.1980.tb04800.x

Lehmann FE (1938) Regionale Verschiedenheiten des Organisators von Triton, insbesondere in der vorderen und hinteren Kopfregion, nachgewiesen durch phasenspezifische Erzeugung von Lithium bedingten und operativ bewirkten Regionaldefekten. Wilhelm Roux's Arch Entw-Mech Organ 138:106-158

Lehmann FE, Scholl A (1962) Morphostatische Effekte der Liponsäure und des nicotinsäureamids auf die regenerierende Schwanzspitze von Xenopuslarven. Naturwissenschaften 49:187-188

Ryffel G, Weber R (1971) Kennzeichnung der RNS aus verschiedenen Organen von Xenopuslarven und ihre Beeinflussung durch Thyroxin. Rev Suisse Zool; annales de la Société zoologique suisse et du Museum d'histoire naturelle de Genève 78:639-650
Ryffel G, Weber R (1973) Changes in the pattern of RNA synthesis in different tissues of Xenopus larvae during induced metamoprhosis. Exp Cell Res 77:79-88. doi:10.1016/0014-4827(73)90555-7

Ryffel GU, Wahli W, Weber R (1977) Quantitation of vitellogenin messenger RNA in the liver of male Xenopus toads during primary and secondary stimulation by estrogen. Cell 11:213-221

Ryffel GU, Wyler T, Muellener DB, Weber R (1980) Identification, organization and processing intermediates of the putative precursors of Xenopus vitellogenin messenger RNA. Cell 19:53-61. doi:10.1016/ 0092-8674(80)90387-6

Ryffel GU, Muellener DB, Wyler T, Wahli W, Weber R (1981) Transcription of single-copy vitellogenin gene of Xenopus involves expression of middle repetitive DNA. Nature 291:429-431

Stadler H, Weber R (1970) Autoradiographische Untersuchungen über die Frühwirkung von Thyroxin auf die RNS-Synthese im Gehirn von Xenopuslarven. Rev Suisse Zool; annales de la Société zoologique suisse et du Museum d'histoire naturelle de Genève 77:587-596

Wahli W, Wyler T, Weber R, Ryffel GU (1976) Size, complexity and abundance of a specific poly(A)-containing RNA of liver from male Xenopus induced to vitellogenin synthesis by estrogen. Eur $\mathrm{J}$ Biochem 66:457-465. doi:10.1111/j.1432-1033.1976.tb10570.x

Wahli W, Ryffel GU, Wyler T, Jaggi FB, Weber R, Dawid IB (1978) Cloning and characterization of synthetic sequences from the Xenopus iaevis vitellogenin structural gene. Dev Biol 67:371-383

Wahli W, Dawid IB, Ryffel GU, Wyler T, Jaggi RB, Weber R (1979) Vitellogenin in Xenopus laevis is encoded in a small family of genes. Cell 16:535-549. doi:10.1016/0092-8674(79)90028-X

Wahli W, Dawid IB, Wyler T, Weber R, Ryffel GU (1980) Comparative analysis of the structural organization of two closely related vitellogenin genes in X. laevis. Cell 20:107-117. doi:10.1016/00928674(80)90239-1

Wahli W, Dawid I, Ryffel G, Weber R (1981) Vitellogenesis and the vitellogenin gene family. Science 212:298-304. doi:10.1126/ science. 7209528

Weber R (1949) Transitorische Verschlüsse von Fernsinnesorganen in der Embryonalperiode bei Amnioten. Kundig, Genève

Weber R (1962) Induced metamorphosis in isolated tails of Xenopus larvae. Experientia 18:84-85. doi:10.1007/bf02138272

Weber R (1966) On the mechanism of action of thyroxin in the metamorphosis of amphibia. Rev Suisse Zool; annales de la Société zoologique suisse et du Museum d'histoire naturelle de Genève 73:559-567 